\title{
Variation of Moho Depth across Bangong-Nujiang Suture in Central Tibet-Results from Deep Seismic Reflection Data
}

\author{
Zhanwu Lu1,2,3*, Rui Gao',2,3, Hongqiang Li ${ }^{1,2,3}$, Wenhui Li1 ${ }^{1,2,3}$, Xiaosong Xiong ${ }^{1,2,3}$ \\ ${ }^{1}$ Key Laboratory of Earthprobe and Geodynamics, Ministry of Land and Resources of PRC, Beijing, China \\ ${ }^{2}$ State Key Laboratory of Continental Tectonics and Dynamics, Beijing, China \\ ${ }^{3}$ Institute of Geology, Chinese Academy of Geological Science, Beijing, China \\ Email: Iuzhanwu78@163.com
}

Received 10 June 2015; accepted 4 August 2015; published 7 August 2015

Copyright (C) 2015 by authors and Scientific Research Publishing Inc.

This work is licensed under the Creative Commons Attribution International License (CC BY).

http://creativecommons.org/licenses/by/4.0/

(c) (i) Dpen Access

\begin{abstract}
There is a long-term dispute at Moho depth across the Bangong-Nujiang suture (BNS). Due to the complicated and changeable seismic geological condition, it is not easy to acquire images of the reflective Moho in central Tibet. In the support of the SinoProbe project, a series of deep seismic reflection profiles were conducted to image Moho structure across the BNS and the Qiangtang terrane. These profiles extend from the northern Lhasa terrane to the Qiangtang terrane crossing the BNS. Both shot gathers and migration data show clear Moho images beneath the BNS. The Moho depth varies from $75.1 \mathrm{~km}(\sim 24 \mathrm{~s}$ TWT) beneath the northmost Lhasa terrane to $68.9 \mathrm{~km}(\sim 22 \mathrm{~s}$ TWT) beneath southmost Qiangtang terrane, and rises smoothly to $62.6 \mathrm{~km}(\sim 20 \mathrm{~s}$ TWT $)$ at $\sim 28$ $\mathrm{km}$ north of the BNS beneath the Qiangtang terrane. We speculate that the Moho appears a $6.2 \mathrm{~km}$ sharp offset across the BNS and becomes $\sim 12.5 \mathrm{~km}$ shallower from the northmost Lhasa terrane to the south Qiangtang terrane at $\sim 28 \mathrm{~km}$ north of the BNS. The viewpoint of Moho depth across the BNS based on deep seismic reflection data is inconsistent with the previous $20 \mathrm{~km}$ offset.
\end{abstract}

\section{Keywords}

Moho Depth, Deep Seismic Reflection, Bangong-Nujiang Suture, Tibet

\section{Introduction}

Though the Bangong-Nujiang suture (BNS) and Qiangtang terrane area in central Tibet are usually considered

${ }^{*}$ Corresponding author.

How to cite this paper: Lu, Z.W., Gao, R., Li, H.Q., Li, W.H. and Xiong, X.S. (2015) Variation of Moho Depth across Bangong-Nujiang Suture in Central Tibet-Results from Deep Seismic Reflection Data. International Journal of Geosciences, 6, 821-830. http://dx.doi.org/10.4236/ijg.2015.68066 
as the good places for understanding the collision of continent-continent, the deep crustal structure of this area is still not clear. Many geophysical studies displayed the deep structures of the lithosphere of the Qiangtang terrane and surrounding zones. Meissner et al. [1] imaged a north dipping Asian slab rooted under the BNS, which could correspond to a northward subduction of the south Tibet. The slab could be around $100 \mathrm{~km}$ long. Shi et al. [2] suggested that a south-dipping crustal converter was seen from the upper crust near the metamorphic core complex exposures in the Qiangtang terrane to the lower crust near the BNS. At deeper depths, a southeast-dipping mantle converter is seen extending from $\sim 50 \mathrm{~km}$ to the north of the BNS at the depth of the Moho to $\sim 100$ $\mathrm{km}$ to the south of the BNS at a depth of $\sim 180 \mathrm{~km}$. The Indian lithosphere has been imaged as far north as central Tibet near the BNS zone [3]-[5]. P-wave velocity structure showed that the Indian lithospheric mantle had subducted beneath central Tibet and that its frontier had passed through the BNS and extended northward beneath the Qiangtang Terrane at latitude $34^{\circ} \mathrm{N}[6]$.

Recent results indicated that the subhorizontally underthrusting Indian mantle lithosphere reached as far as $\sim 100 \mathrm{~km}$ to the north of the BNS $\left(\sim 33^{\circ} \mathrm{N}\right)[7][8]$ and that the underthrusing Indian lowers crust slid to latitude $\sim 31^{\circ} \mathrm{N}[9]$.

However, existing researches cannot provide fine image of crustal structure and Moho depth across the BNS. Over the last 30 years, deep seismic reflection profiling had been demonstrated to be an effective method in resolving the structural details in the crustal and upper mantle [10]. A lot of deep seismic profiling projects have provided a great number of seismic lines that image the structure of the continental crust and the crust-mantle boundary [11]-[15]. This approach was proved to be particularly successful in studying the tectonic development of southern Tibet in the early 1990s [16]-[18]. However, it is not easy to acquire images of the reflective Moho in central Tibet due to the severe topography, the rapid velocity and thickness variations of near-surface layers, and strong seismic attenuation through the thickest crust of the Earth.

To test the acquisition technique for detecting the Moho structure in central Tibet, SinoProbe Project performs a deep seismic reflection profile, which starts west of Selin Co in the northern Lhasa terrane, crosses the Bangong Nujiang Suture (BNS) to the west of Lunpola, skirts the eastern extension of the central Qiantang anticline and ends at Dogai Coring just to the south of the Jinsha Suture (JS). In SinoProbe deep seismic reflection profile, large seismic sources with $1000 \mathrm{~kg}$ of explosives have been detonated in the Qiangtang terrane and good quality data are acquired. In this paper, we just report the single shot records of $1000 \mathrm{~kg}$ explosive and migration section across the BNS (Figure 1).

\section{Geological Setting}

The Tibetan Plateau is always considered as ideal window for studying the geological evolution of the continent-continent collision. Since the Cenozoic the collision and the convergence between the Indian and Eurasian plates resulted in the building of the main body of the Tibet Plateau. From south to north, several terranes named Himalayan, Lhasa, Qiangtang, Songpan-Ganzi and Kunlun-Qaidam terrans developed in Tibet. These tarranes are separated by a series of east-west-trending suture zones [19]-[21]. The Qiangtang terrane lies between the JS to the north and the BNS to the south (Dewey et al. 1988; Yin and Harrison, 2000). It is about $500-600 \mathrm{~km}$ wide in central Tibet, but narrows to $150 \mathrm{~km}$ both to the west and the east in the western Kunlun and eastern Tibet. As the south boundary of the Qiangtang terrane, the BNS represents the tectonic junction between the Lhasa terrane in the south and the Qiangtang terrane in the north. This suture was originally formed during a late Jurassic-Early Cretaceous collision between these two terranes and defined by a broad and discontinuous belt of ophiolite fragments and mélange [19] [22]-[25]. It represents remnants of a major oceanic basin that opened before the Triassic and closed by northward subduction beneath the Qiangtang terrane in the Middle to Late Jurassic [26]-[28]. During mid-Cretaceous time, the BNS was characterized by volcanism and nonmarine basin development. Tertiary deformation in this zone is characterized by mainly north-dipping thrust systems with Eocene-Oligocene red beds and volcanic rocks in the footwall. Tertiary shortening and basin development in central Tibet may record continued Lhasa terrane underthrusting along the BNS, which may have both accommodated and been driven by insertion of Indian basement into a previously thickened Tibetan crust (Figure 2) [24].

\section{Data Acquisition and Processing}

\subsection{Deep Seismic Reflection Data Acquisition}

From October 2009 to May 2010, a $310 \mathrm{~km}$ deep seismic reflection profile was acquired used explosive sources 


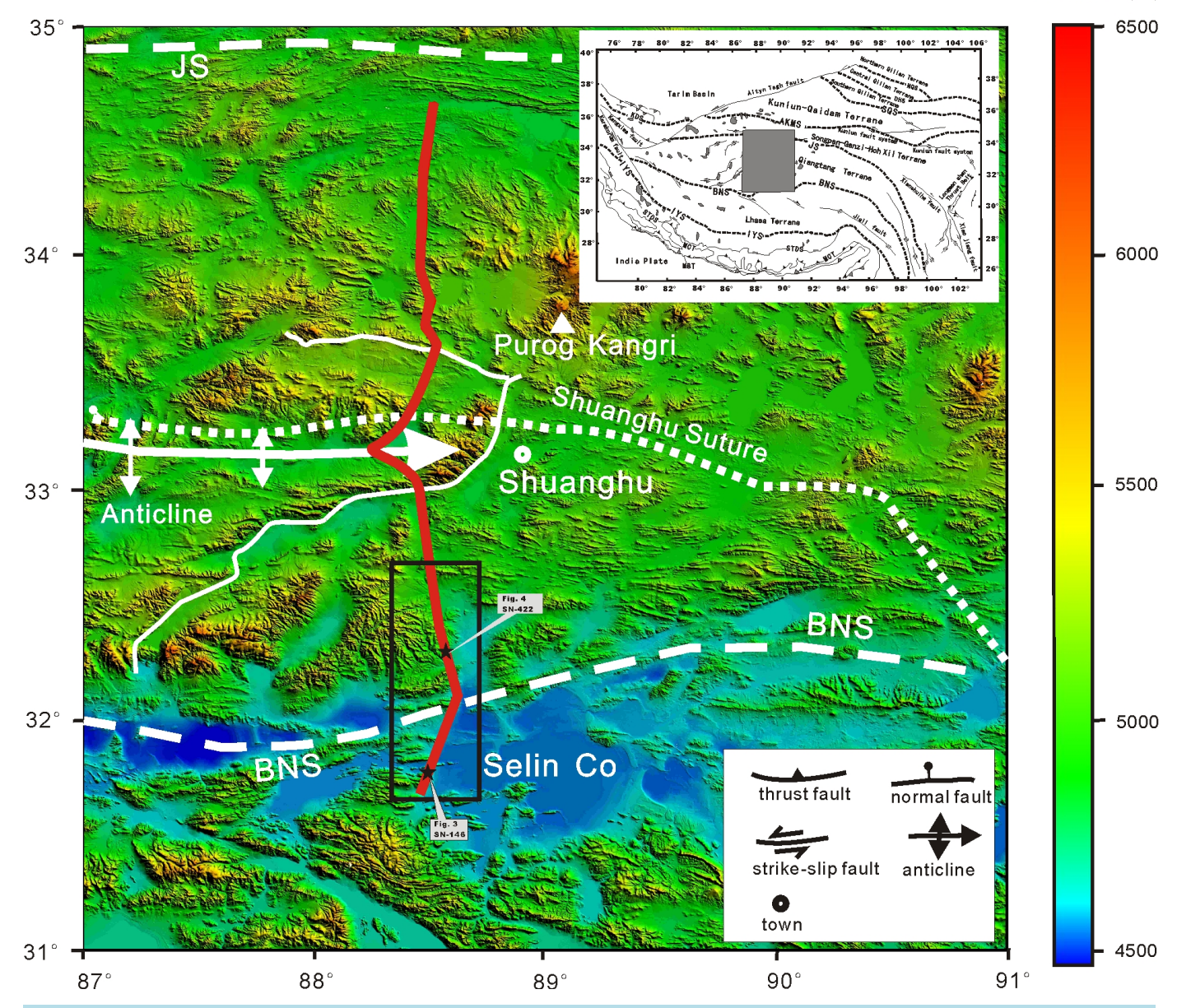

Figure 1. Location map of the deep seismic reflection profile. BNS-Bangong Nujiang suture. The red solid line shows the seismic reflection profile. The black stars mark the locations of large shots using $1000 \mathrm{~kg}$ explosive fired at the both sides of the BNS. The black box shows the research areas in this paper.

with variable shot sizes. In the southern part of the profile across the BNS, small shots of $50 \mathrm{~kg}$ explosives were placed at $250 \mathrm{~m}$ interval, augmented by medium shots of $200 \mathrm{~kg}$ spaced every $1 \mathrm{~km}$ and large shots of $1000 \mathrm{~kg}$ spaced every $50 \mathrm{~km}$. A linear array of receivers was used with a group interval of $50 \mathrm{~m}$. The data was acquired by Sercel $408 \mathrm{XL}$ using 720 channels. We designed the drilling depth of the holes as $30 \mathrm{~m}$ for small shots and 50 $\mathrm{m}$ for medium and large explosive shots in order to fire at the high-velocity layer. Single $30 \mathrm{~m}$-depth hole was drilled for a small-size shot of $50 \mathrm{~kg}$. Double $50 \mathrm{~m}$-depth holes were drilled for a medium shot of $200 \mathrm{~kg}$. Ten 50 m-depth holes were drilled as a circle for a large shot of $1000 \mathrm{~kg}$ with each hole of $100 \mathrm{~kg}$ explosive. These holes were drilled by powerful machines ( $235 \mathrm{~kW}$ each) to ensure the drilling depth. In the field, especially in Tibet, strong wind can greatly degrade the data quality. To avoid the interference of the wind, we placed geophones into the pit and monitored these geophones every day to choose the optimal firing time with the least interference. In this paper, we only talk about part of the profile and large shot gathers between the BNS.

\subsection{Data Processing of Single Shot Gathers}

In this profile, rugged topography, wind noise, various geological structures and poor explosive energy penetration are main factors that affect the quality of the recorded data. In order to obtain high quality data, a few crucial methods including bandpass filter, noise suppression, FK power are used in single shot gather data processing. The data processing flow for single shot gather is shown in Figure 2. Because of the energy attenuation relating to overlaying the high-velocity layer in a local station, some channels in the raw data become weak in energy. We applied the FK power module to enhance the signal in a window of seismic data. The program 


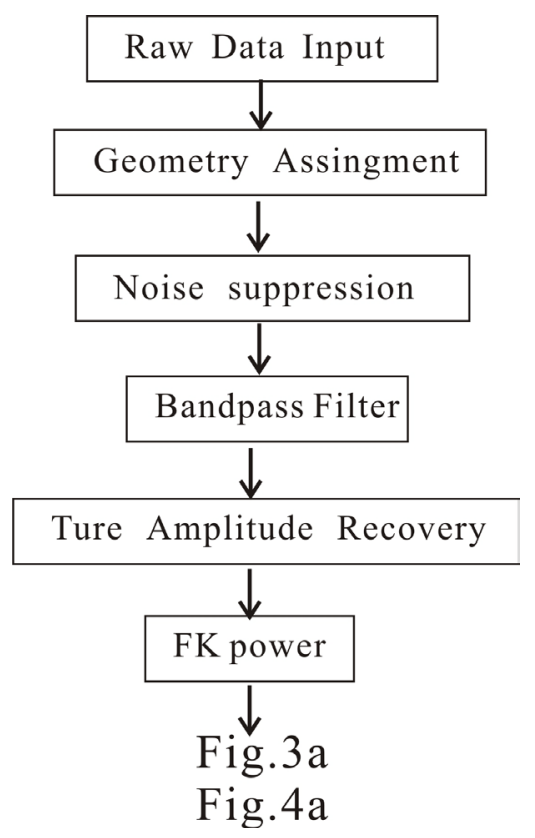

Figure 2. The data processing flow for the large shot gathers across the BNS.

performs a multichannel, time variant operation. In the processing, a window of data is transformed into the FK domain. The amplitude of each FK sample is modified by raising it to a user-specified power, while the phase of the FK-domain sample remains unchanged. An inverse transform back to the time-space domain is performed on the data. The window is advanced by $50 \%$ of the time length, and the process repeats for the new window, with the output linearly tapered between the window centers. When the FK samples are raised to a power greater than one, the energy that is strong and localized in the FK space becomes even stronger. This allows the seismic data to be displayed at a lower gain; therefore, the random noise will appear at much lower amplitude. This process thereby enhances continuous and linear seismic data energy that maps a localized region in the FK spaces. At the same time, the median and band-pass methods are used in this step. We used 6-8-25-30 Hz in 0 $6 \mathrm{~s}$ TWT and 4-6-20-25 Hz in 6.5 - $30 \mathrm{~s}$ TWT as filter parameters.

\section{Results}

In many cases, the lowermost crust was always imaged as a prominent and continuous band of reflectors. The bottom of the continuous band can often be interpreted as the Moho. For example, in the COCORP data [29] and a conventional deep seismic reflection survey in England [30], they interpreted Moho as the bottom of the layered reflections. In addition, amplitude of the reflection events are also necessary to decide Moho. We carried out amplitude analysis of the two large shot gathers between the BNS. The shot gather shown in Figure 3 is fired to the south of the BNS. Figure 4 shows the shot gather fired at $28 \mathrm{~km}$ north to the BNS in the Qiangtang terrane. On the shot gather fired to the south of the BNS at the northernmost Lhasa terrane, there are some continuous reflections from $19.5 \mathrm{~s}$ to $24 \mathrm{~s}$ TWT. Based on the amplitude analysis and the mentioned studies, we interpret the bottom of the continuous reflection group at $24 \mathrm{~s}$ TWT, with the high amplitude as the Moho reflection (Figure 3). The clear reflectors with high reflectivity interpreted as the Moho are well imaged on another larger explosive single shot record fired at $\sim 28 \mathrm{~km}$ north of the BNS. The Moho was indicated with the continuous reflection at $20 \mathrm{~s}$ TWT (Figure 4). The images of Figure 5 show an apparent variation of the Moho reflection across the BNS.

\section{Discussion}

It is well known that the Tibet Plateau has a thicker crust than $45 \mathrm{~km} \mathrm{[31].} \mathrm{Over} \mathrm{past} \mathrm{three} \mathrm{decades,} \mathrm{the} \mathrm{various}$ Moho depth between different terranes and Moho offset under the main suture zones of the Tibetan Plateau were 


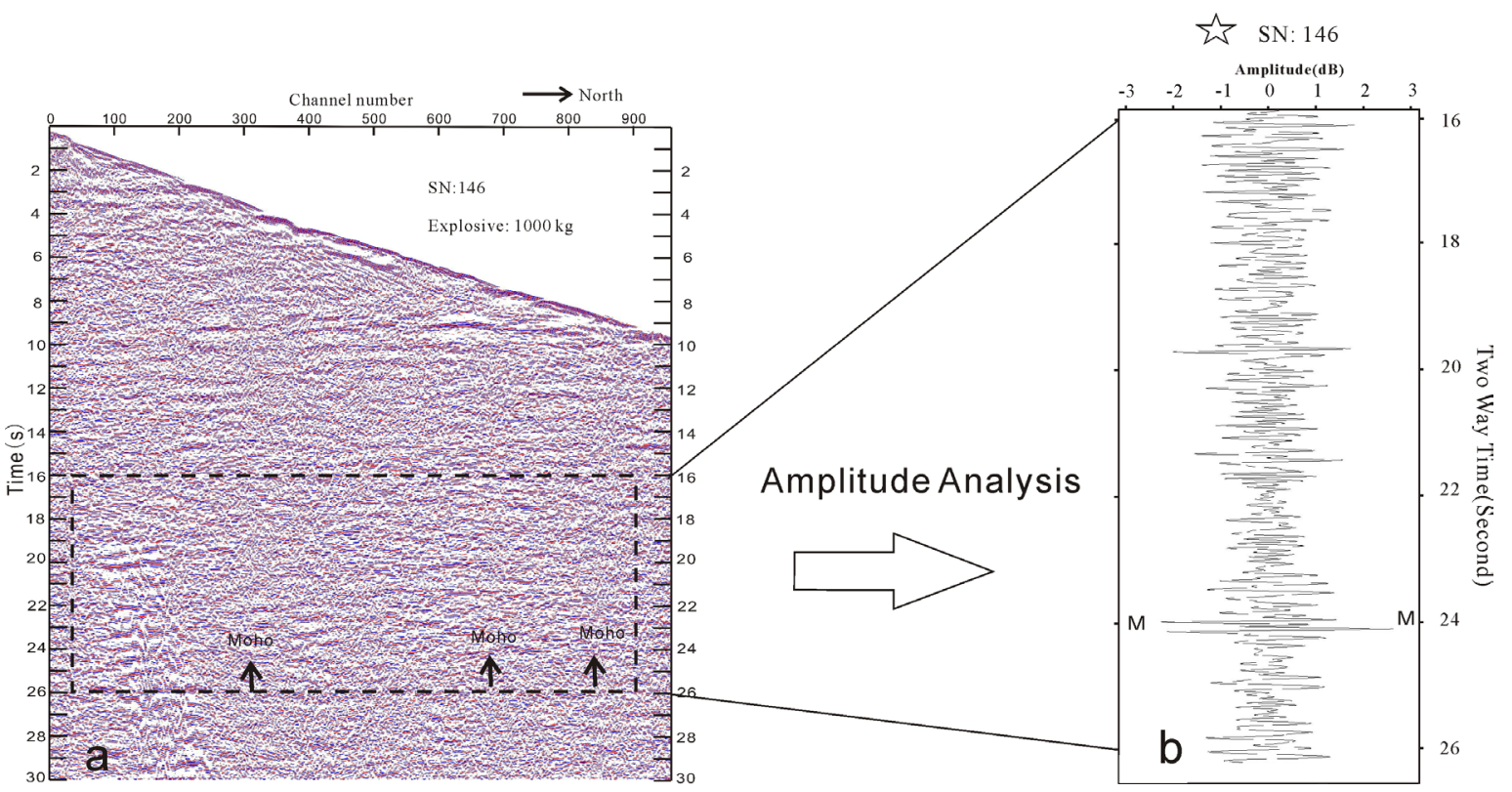

Figure 3. Large shot gathers (a) and amplitude analysis (b) of $1000 \mathrm{~kg}$ of explosives fired in the northernmost Lhasa terrane, south of BNS. SN is shot number. The location is shown in Figure 1.

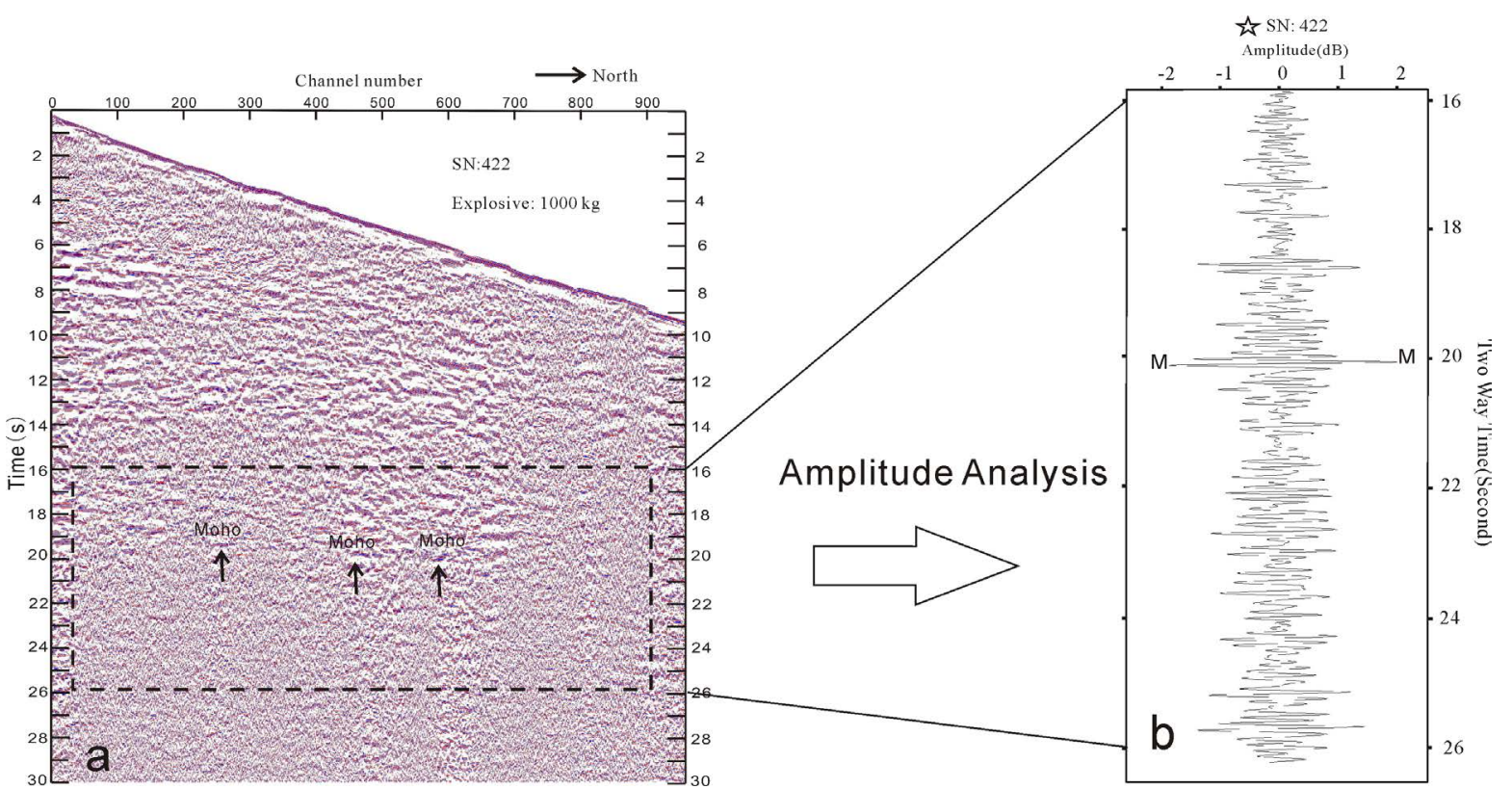

Figure 4. Large shot gather (a) and amplitude analysis (b) of $1000 \mathrm{~kg}$ of explosives fired at $28 \mathrm{~km}$ north of the BNS. SN is shot number. The location is shown in Figure 1.

detected by a series of seismic investigations [32]-[36]. Li et al. [37] discussed the thickness and structural characteristics of the crust across Tibetan plateau from active-sources seismic profiles. However, due to poor coverage of previous surveys and lack of consistency between various seismic techniques, Moho offset beneath the BNS remains controversial.

The Moho across the BNS had been reported as a $\sim 20 \mathrm{~km}$ offset [38], a more than $10 \mathrm{~km}$ offset [39] [40], about $8 \mathrm{~km}$ variation [41], a $\sim 5 \mathrm{~km}$ northward step-up [34] [42], and no evidence of fault offsets [4]. In addition, Shi et al. [2] found a Moho trough with about $5 \pm 3 \mathrm{~km}$ Moho offset under the Bengco-Jiali fault which is $\sim 40$ $\mathrm{km}$ north of the BNS. 
Deep seismic reflection profile could gain a high-resolution structure of the interior Earth. The acquisition of data from large explosions in the U.S. successfully provided a good example for the exploration of deep continental crustal structure [43]. In the SinoProbe project, the 1000-kg shot gathers and migration profile in central Tibet provide clear Moho images beneath the BNS. We interpret the shot gathers records and migration profile together to show the Moho depth variation across the BNS. Based on the single shot (Figure 3), we suggest a $75.1 \mathrm{~km}(\sim 24 \mathrm{~s}$ TWT) Moho depth in the northmost Lhasa terrane. This Moho matches the position a in Figure 6(b). On the other big shot gather fired at $\sim 28 \mathrm{~km}$ north of the BNS to further north (Figure 4), the Moho appear at $62.6 \mathrm{~km}(\sim 20 \mathrm{~s}$ TWT, matching position $\mathbf{c}$ in Figure 6(b)) in the left part and $65.7 \mathrm{~km}(\sim 21 \mathrm{~s} \mathrm{TWT}$, matching position $\mathbf{d}$ in Figure 6(b)) in the right part.

The magnitude of the step across the BNS is $6.2 \mathrm{~km}$ that concluded by the migration data (Figure 6(a)). The Moho depth is $75.1 \mathrm{~km}(\sim 24 \mathrm{~s}$ TWT, position a in Figure 6(b)) in the northmost Lhasa terrane and $68.9 \mathrm{~km}(\sim 22$ $\mathrm{s}$ TWT, position b in Figure 6(b)) in the southmost Qiangtang terrane The step of $6.2 \mathrm{~km}$ is displayedfrom position a to b shown in Figure 6(b). North of the BNS, Moho reflections get smoothly shallower from $68.9 \mathrm{~km}$ $(\sim 22 \mathrm{~s}$ TWT $)$ to $62.6 \mathrm{~km}(\sim 20 \mathrm{~s}$ TWT $)$ in the lateral more than $25 \mathrm{~km}$ surface distance in the south Qiangtang terrane. Then, we think Moho get $12.5 \mathrm{~km}$ shallower from the Lhasa terrane to $\sim 28 \mathrm{~km}$ north of the BNS beneath the Qiangtang terrane displayed by position a to $\mathbf{c}$ in Figure 6(b) and $9.4 \mathrm{~km}$ step to the further north beneath the south Qiangtang terrane and central Qiangtang anticline shown by position a to position $\mathbf{d}$ in Figure 6(b). The Moho variation across the BNS revealed by deep seismic reflection profile (Figure 6(c)) argued against a gradational Moho based on waveform modeling [1] and also not in agreement with a $20-\mathrm{km}$ offset [38].

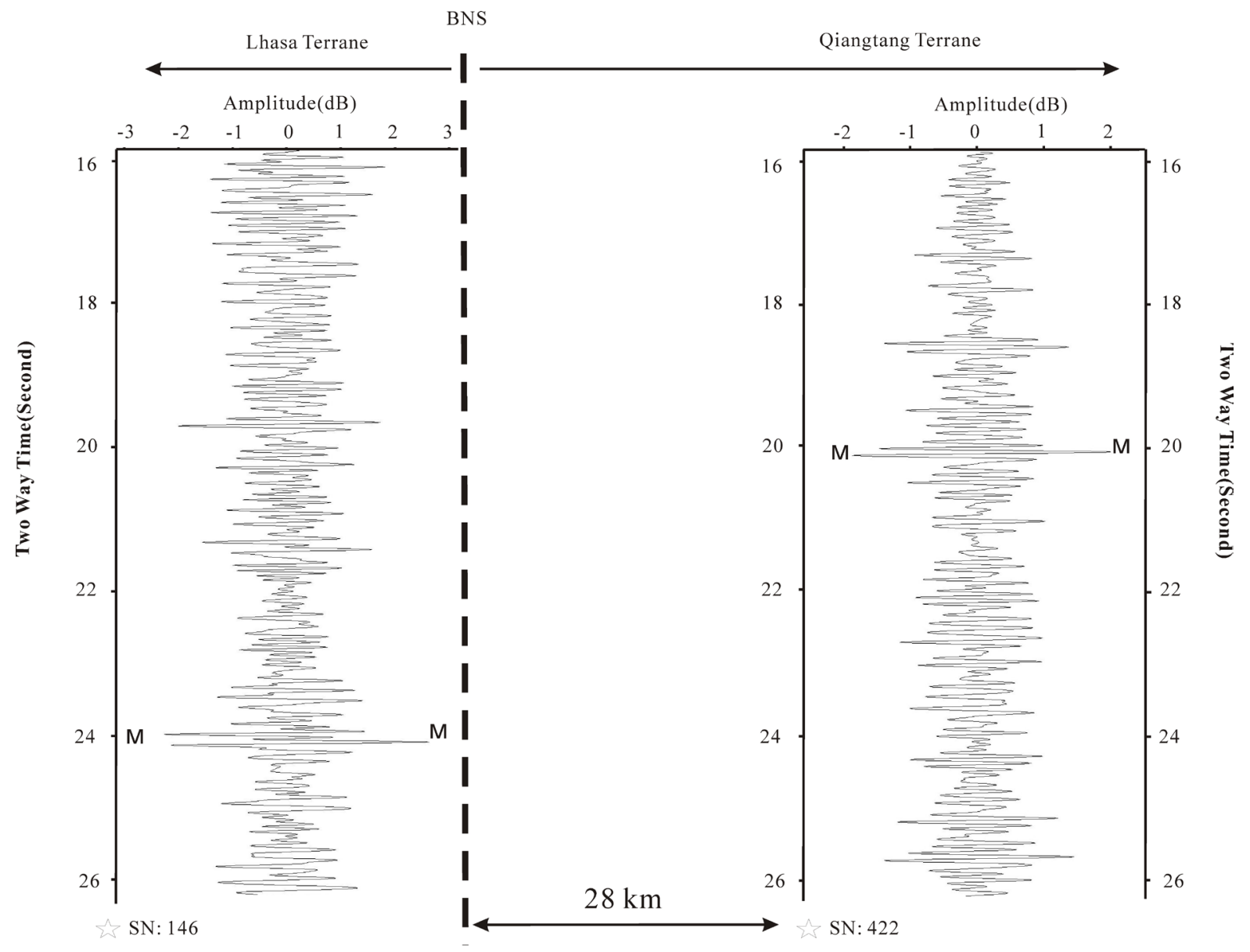

BNS

Figure 5. Amplitude analysis for the two large shot gathers across the BNS. There is an apparent variation of the Moho reflection across the BNS. 


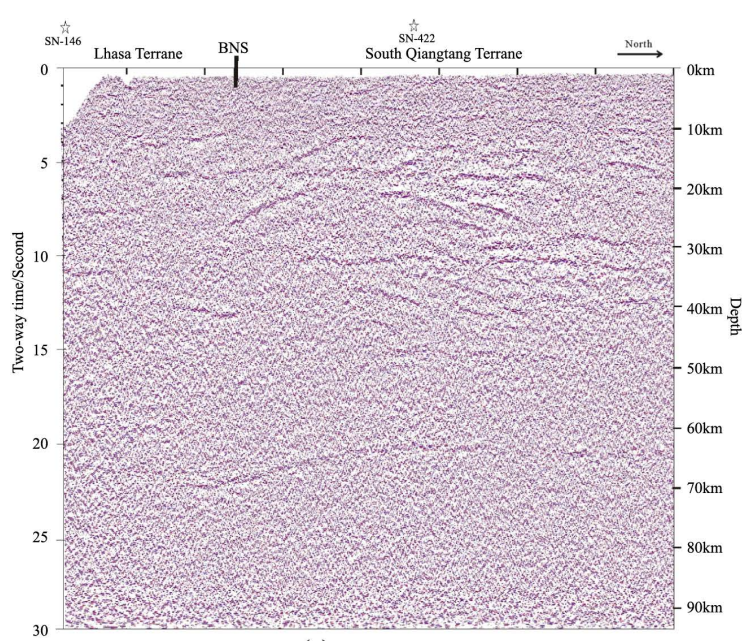

(a)

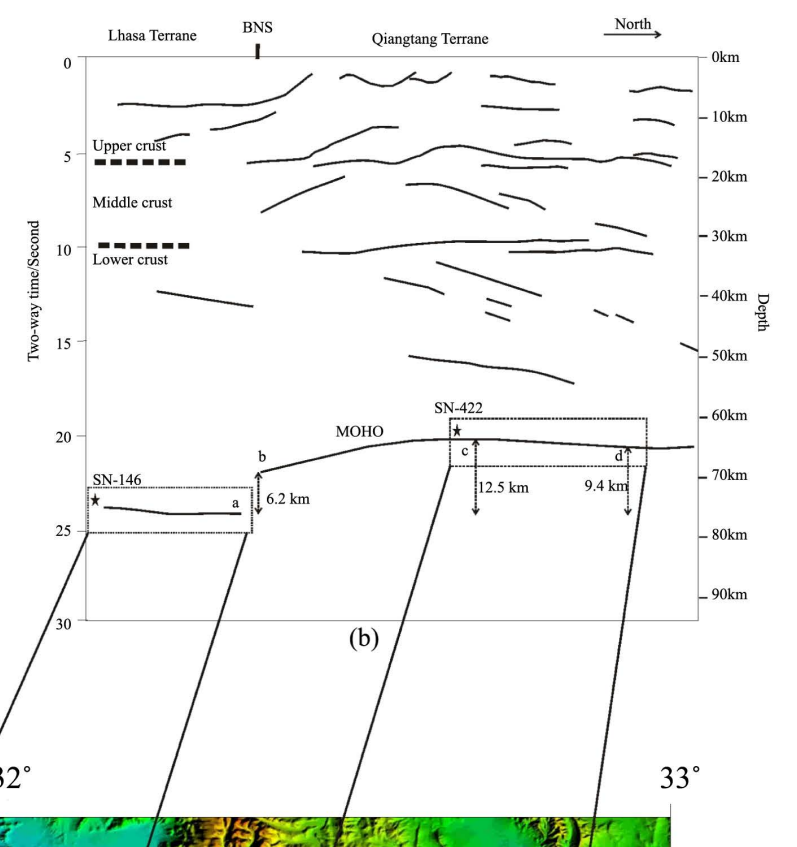

$88^{\circ}$

$31^{\circ}$

$89^{\circ}$

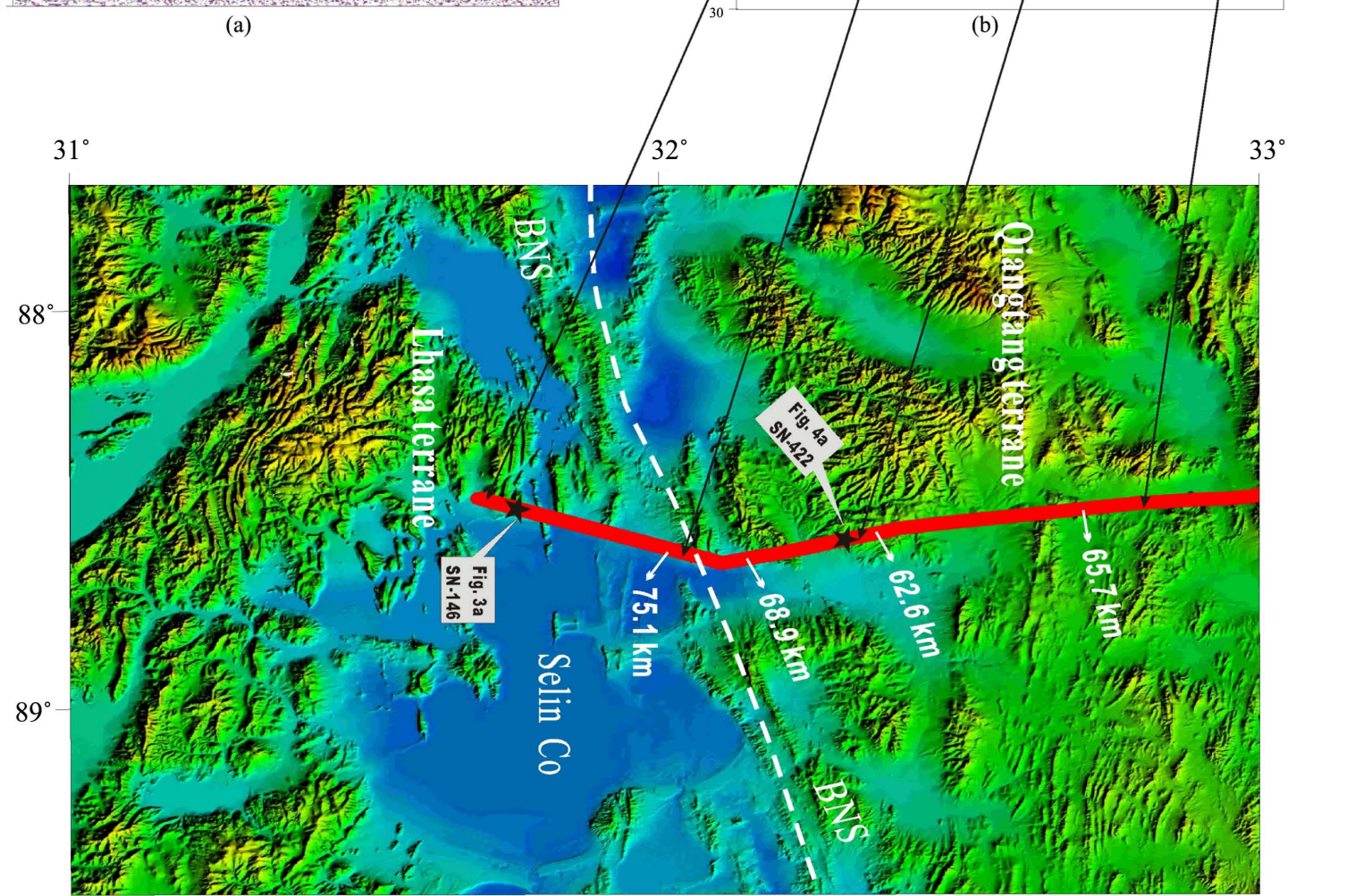

(c)

Figure 6. The interpreted migration profile and topographic map plotted with the Moho depth across the BNS. (a) Migration profile; (b) Interpreted result; (c) Topographic map plotted with the Moho depth to show Moho variation across the BNS.

\section{Conclusion}

There is a Moho offset across the BNS. The step of Moho is about $6.2 \mathrm{~km}$. Moreover, to the north of the BNS, the Moho rises smoothly to $62.6 \mathrm{~km}$, and then becomes $\sim 12.5 \mathrm{~km}$ shallower from the northmost Lhasa terrane to the south Qiangtang terrane at $\sim 28 \mathrm{~km}$ north of the BNS. The viewpoint of Moho depth across the BNS based on deep seismic reflection data is inconsistent with the previous $20 \mathrm{~km}$ offset or no change.

\section{Acknowledgements}

We thank the Fifth Geophysical Prospecting Company of Southwest Petroleum Bureau for their excellent field 
work. We also thank Haiyan Wang for good advice on data processing. This study is funded by the National Natural Science Foundation of China (Nos. 41274096 and 41430213) and the Ministry of Land and Resources of China (Nos. 201311159; SinoProbe-02-06; SinoProbe-02-01).

\section{References}

[1] Meissner, R. Tilmann, F. and Haines, S. (2004) About the Lithospheric Structure of Central Tibet, Based on Seismic Data from the INDEPTH III Profile. Tectonophysics, 380, 1-25. http://dx.doi.org/10.1016/j.tecto.2003.11.007

[2] Shi, D.N., Zhao, W.J., Brown, L., Nelson, D., Zhao, X., Kind, R., Ni, James., Xiong, J.Y., Mechie, J., Guo, J.R., Klemperer, S. and Hearn, T. (2004) Detection of Southward Intracontinental Subduction of Tibetan Lithosphere along the Bangong-Nujiang Suture by P-to-S Converted Waves. Geology, 32, 209-212. http://dx.doi.org/10.1130/G19814.1

[3] Huang, W., Ni, J.F., Tilmann, F., Nelson, D., Guo, J.R., Zhao, W.J., Mechie, J., Kind, R., Saul, J., Rapine, R. and Hearn, T.M. (2000) Seismic Polarization Anisotropy beneath the Central Tibetan Plateau. Journal of Geophysical Research, 105, 27979-27989. http://dx.doi.org/10.1029/2000JB900339

[4] Kind, R., Yuan, X., Saul, J., Nelson, D. and Sobolev, V.S. (2002) Seismic Images of Crust and Upper Mantle beneath Tibet: Evidence for Eurasian Plate Subduction. Science, 298, 1219-1221. http://dx.doi.org/10.1126/science.1078115

[5] Tilmann, F. and Ni, J. (2003) Seismic Imaging of the Downwelling Indian Lithosphere beneath Central Tibet. Science, 300, 1424-1427. http://dx.doi.org/10.1126/science.1082777

[6] He, R.Z., Zhao, D.P., Gao. R. and Zheng, H.W. (2010) Tracing the Indian Lithospheric Mantle beneath Central Tibetan Plateau Using Teleseismictomography. Tectonophysics, 491, 230-243. http://dx.doi.org/10.1016/j.tecto.2010.03.015

[7] Xu, Q., Zhao, J.M., Pei, S.P. and Liu, H.B. (2011) The Lithosphere-Asthenosphere Boundary Revealed by S-Receiver Functions from the Hi-CLIMB Experiment. Geophysical Journal International, 187, 414-420. http://dx.doi.org/10.1111/j.1365-246X.2011.05154.x

[8] Chen, W.P., Hung, S., Tseng, T. and Brudzinski, M. (2012) Rheology of the Continental Lithosphere: Progress and New Perspectives. Gondwana Research, 21, 4-18. http://dx.doi.org/10.1016/j.gr.2011.07.013

[9] Nábělek J., Hetényi, G., Vergne, J., Sapkot, S., Kafle, B., Jiang, M., Su, H.P., Chen, J. and Huang, B.S., The HiCLIMB Team (2009) Underplating in the Himalaya-Tibet Collision Zone Revealed by the Hi-CLIMB Experiment. Science, 325, 1371-1374. http://dx.doi.org/10.1126/science.1167719

[10] Oliver, J. (1982) Probing the Structure of the Deep Continental Crust. Science, 216, 689-695. http://dx.doi.org/10.1126/science.216.4547.689

[11] Brown, L., Wille, D., Zheng, L., Devoogd, B., Maye, J., Hearn, T., Sanford, W., Caruso, C., Zhu, T.F., Nelson, D., Potter, C., Hauser, E., Klemperer, S., Kaufman, S. and Oliver, J. (1987) COCORP: New Perspectives on the Deep Crust. Geophysical Journal International, 89, 47-54. http://dx.doi.org/10.1111/j.1365-246X.1987.tb04386.x

[12] Clowes, R.M., Yorath, C.J. and Hyndman, R.D. (1987) Reflection Mapping across the Convergent Margin of Western Canada. Geophysical Journal International, 89, 79-84. http://dx.doi.org/10.1111/j.1365-246x.1987.tb04391.x

[13] Klemperer, S.L., Hobbs, R.W. and Freeman, B. (1990) Dating the Source of Lower Crustal Reflectivity Using BIRPS Deep Seismic Profiles across the Lapetus Suture. Tectonophysics, 173, 445-454. http://dx.doi.org/10.1016/0040-1951(90)90237-3

[14] Balling, N. (2000) Deep Seismic Reflection Evidence for Ancient Subduction and Collision Zones within the Continental Lithosphere of Northwestern Europe. Tectonophysics, 329, 269-300. http://dx.doi.org/10.1016/S0040-1951(00)00199-2

[15] Cook, F.A., White, D.J., Jones, A.G., Eaton, D., Hall, J. and Clowes, R.M. (2010) How the Crust Meets the Mantle: Lithoprobe Perspectives on the Mohorovicic Discontinuity and Crust-Mantle Transition. Canadian Journal of Earth Sciences, 47, 315-351. http://dx.doi.org/10.1139/E09-076

[16] Zhao, W.J., Nelson, K.D., Che, J.K., Guo, J.R., Lu, D.Y., Wu, C.L. and Liu, X. (1993) Deep Seismic Reflection Evidence for Continental Underthrusting beneath Southern Tibet. Nature, 366, 557-559. http://dx.doi.org/10.1038/366557a0

[17] Nelson, K.D., Zhao, W.J., Brown, L.D., Kuo, J., Che, J.K., Liu, X.W., Klemperer, S.L., Makovsky, Y., Meissner, R., Mechie, J., Kind, R., Wenzel, F., Ni, J., Nabelek, J., Chen, L.S., Tan, H.D., Wei, W.B., Jones, A.G., Booker, J., Unsworth, M., Kidd, W.S.F., Hauck, M., Alsdorf, D., Ross, A., Cogan, M., Wu, C.D., Sandvol, E. and Edwards, M. (1996) Partially Molten Middle Crust beneath Southern Tibet: Synthesis of Project INDEPTH Results. Science, 274, 16841688. http://dx.doi.org/10.1126/science.274.5293.1684

[18] Brown, L.D., Zhao, W.J., Nelson, K.D., Hauck, M., Alsdorf, D., Ross, A., Cogan, M., Clark, M., Liu, X. and Che, J. (1996) Bright Spots, Structure, and Magmatism in Southern Tibet from INDEPTH Seismic Reflection Profiling. Science, 274, 1688-1690. http://dx.doi.org/10.1126/science.274.5293.1688 
[19] Yin, A. and Harrison, T.M. (2000) Geologic Evolution of the Himalayan-Tibetan Orogen. Annual Review of Earth and Planetary Sciences, 28, 211-280. http://dx.doi.org/10.1146/annurev.earth.28.1.211

[20] Tapponnier, P., Xu, Z.Q., Roger, F., Meyer, B., Arnaud, N., Wittlinger, G. and Yang, J.S. (2001) Oblique Stepwise Rise and Growth of the Tibet Plateau. Science, 294, 1671-1677. http://dx.doi.org/10.1126/science.105978

[21] Chung, S., Chu, M., Zhang, Y.Q., Xie, Y.W., Lo, C., Lee, T., Lan, C., Li, X.H., Zhang, Q. and Wang, Y.Z. (2005) Tibetan Tectonic Evolution Inferred from Spatial and Temporal Variations in Post-Collisional Magmatism. EarthScience Reviews, 68, 173-196. http://dx.doi.org/10.1016/j.earscirev.2004.05.001

[22] Kapp, P., Yin, A., Manning, C.E., Harrison, T.M., Taylor, M.H. and Ding, L. (2003) Tectonic Evolution of the Early Mesozoic Blueschist-Bearing Qiangtang Metamorphic Belt, Central Tibet. Tectonics, 22, 1043-1052. http://dx.doi.org/10.1029/2002TC001383

[23] Kapp, P., Decelles, P.G., Gehrels, G.E., Heizler, M. and Ding, L. (2007) Geological Records of the Lhasa-Qiangtang and Indo-Asian Collisions in the Nima Area of Central Tibet. Geological Society of American Bulletin, 119, 917-933. http://dx.doi.org/10.1130/B26033.1

[24] Guynn, J.H., Kapp, P., Pullen, A., Heizler, M., Gehrels, G. and Ding, L. (2006) Tibetan Basement Rocks Near Amdo Reveal "Missing" Mesozoic Tectonism along the Bangong Suture, Central Tibet. Geology, 34, 505-508. http://dx.doi.org/10.1130/G22453.1

[25] Wu, Z.H., Ye, P.S., Barosh, P.J., Hu, D.G. and Lu, L. (2013) Early Cenozoic Multiple Thrust in the Tibetan Plateau. Journal of Geological Research, 2013, Article ID: 784361. http://dx.doi.org/10.1155/2013/784361

[26] Girardeau, J., Marcoux, J., Allegre, C.J., Bassoullet, J.P., Tang, Y.K., Xiao, X.C., Zao, Y.G. and Wang, X.B. (1984) Tectonic Environment and Geodynamic Significance of the Neo-Cimmerian Donqiao Ophiolite, Bangong-Nujiang Suture Zone, Tibet. Nature, 307, 27-31. http://dx.doi.org/10.1038/307027a0

[27] Pearce, J.A. and Deng, W.M. (1988) The Ophiolites of the Tibetan Geotraverses, Lhasa to Golmud (1985) and Lhasa to Kathmandu (1986). Philosophical Transactions of the Royal Society A, 327, 215-238. http://dx.doi.org/10.1098/rsta.1988.0127

[28] Wang, W., Aitchison, J.C., Lo, C. and Zeng, Q.G. (2008) Geochemistry and Geochronology of the Amphibolite Blocks in Ophioliticmelanges along Bangong-Nujiang Suture, Central Tibet. Journal of Asian Earth Sciences, 33, 122-138. http://dx.doi.org/10.1016/j.jseaes.2007.10.022

[29] Klemperer, S.L. (1989) Deep Seismic Reflection Profiling and the Growth of the Continental Crust. Tectonophysics, 161, 234-244. http://dx.doi.org/10.1016/0040-1951(89)90156-X

[30] Warner, M., Spaargaren, B., Jones, R., Watts, D. and Doody, J. (1994) High-Resolution Images of the Lower Crust: Deep Seismic Reflections from 15 to 80 Hz. Tectonophysics, 232, 225-237. http://dx.doi.org/10.1016/0040-1951(94)90086-8

[31] Liu, Y.K. and Liu, F.T. (1998) Three-Dimensional Velocity Iages beneath the Chinese Continent. Geoscience Journal, 2, 117-123. http://dx.doi.org/10.1007/BF02910255

[32] Zhu, L.P. and Helmberger, D.V. (1998) Moho Offset across the Northern Margin of the Tibetan Plateau. Science, 281, 1170-1172. http://dx.doi.org/10.1126/science.281.5380.1170

[33] Vergne, J., Wittlinger, G., Qian, H., Tapponnier, P., Poupinet, G., Jiang, M., Herquel, G. and Paul, A. (2002) Seismic Evidence for Stepwise Thickening of the Crust across the NE Tibetan Plateau. Earth and Planetary Science Letters, 203, 25-33. http://dx.doi.org/10.1016/S0012-821X(02)00853-1

[34] Haines, S.S., Klemperer, S.L., Brown, L., Guo. J., Mechie, J., Meissner, R., Ross, A. and Zhao, W. (2003) INDEPTH III Seismic Data: From Surface Observations to Deep Crustal Processes in Tibet. Teoctonics, 22, 1-18. http://dx.doi.org/10.1029/2001tc001305

[35] Shi, D.N., Shen, Y., Zhao, W.J. and Li, A.B. (2009) Seismic Evidence for a Moho Offset and South-Directed Thrust at the Easternmost Qaidam-Kunlun Boundary in the Northeast Tibetan Plateau. Earth and Planetary Science Letters, 288, 329-334. http://dx.doi.org/10.1016/j.eps1.2009.09.036

[36] Zhang, Z.J., Klemperer, S.L., Bai, Z.M., Chen, Y. and Teng, J.W. (2011) Crustal Structure of the Paleozoic Kunlun Orogeny from an Active-Source Seismic Profile between Moba and Guide in East Tibet, China. Gondwana Research, 19, 994-1007. http://dx.doi.org/10.1016/j.gr.2010.09.008

[37] Li, Q.S., Gao, R., Lu, Z.W., Guan, Y., Zhang, J.S., Li, P.W., Wang, H.Y., He, R.Z. and Karplus, M. (2009) The Thickness and Structural Characteristics of the Crust across Tibetan Plateau from Active-Sources Seismic Profiles. Earthquake Science, 22, 21-31. http://dx.doi.org/10.1007/s11589-009-0021-6

[38] Hirn, A., Nercessian, A., Sapin, M., Jobert, G., Xu, Z.X., Gao, E.Y., Lu, D.Y. and Teng, J.W. (1984) Lhasa Block and Bordering Sutures-A Continuation of a 500-km Moho Traverse through Tibet. Nature, 307, 25-27. http://dx.doi.org/10.1038/307025a0 
[39] Zeng, R.S., Ding, Z.F. and Wu, Q.J. (1995) A Review on the Lithospheric Structures in Tibetan Plateau and Constraints for Dynamics. Pure and Applied Geophysics, 145, 425-443. http://dx.doi.org/10.1007/BF00879582

[40] Tseng, T., Cheng, W. and Nowack, R.L. (2009) Northward Thinning of Tibetan Crust Revealed by Virtual Seismic Profiles. Geophysical Research Letters, 36, Article ID: L24304. http://dx.doi.org/10.1029/2009gl040457

[41] Li, Y.H., Wu, Q.J., Tian, X.B., Zeng, R.S., Zhang. R.Q. and Li, H.G. (2006) Crustal Structure beneath Qiangtang and Lhasa Terrane from Receiver Function. Acta Seismologica Sinica, 19, 633-642. http://dx.doi.org/10.1007/s11589-006-0633-Z

[42] Zhao, W.J., Mechie, J., Brown, L.D., Guo, J.R., Haines, S., Hearn, T., Klemperer, S.L., Ma, Y.S., Meissner, R., Nelson, K.D., Ni, J.M., Pananont, P., Rapine, R., Ross, A. and Saul, J. (2001) Crustal Structure of Central Tibet as Derived from Project INDEPTH Wide-Angle Seismic Data. Geophysical Journal International, 145, 486-498. http://dx.doi.org/10.1046/j.0956-540x.2001.01402.x

[43] Jarchow, C.M., Goodwin, E.B. and Catchings, R.D. (1990) Are Large Explosive Sources Applicable to Resource Exploration? The Leading Edge, 9, 12-17. http://dx.doi.org/10.1190/1.1439667 